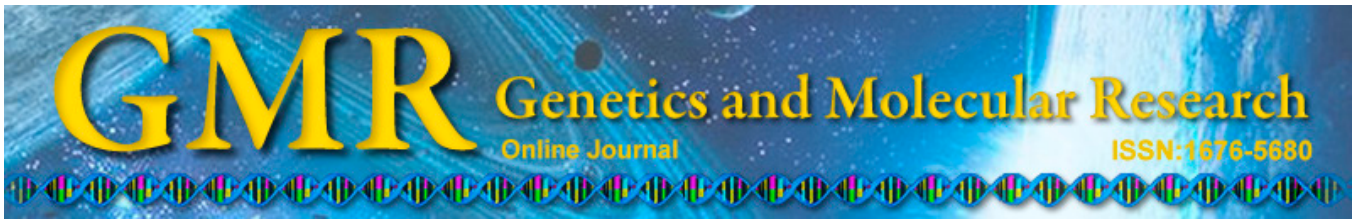

\title{
An economical and combined method for rapid and efficient isolation of fungal DNA
}

\author{
T. Lech, J. Syguła-Cholewinska and J. Szostak-Kot \\ Department of Microbiology, Faculty of Commodity Science, \\ Cracow University of Economics, Krakow, Poland \\ Corresponding author: T. Lech \\ E-mail: lecht@uek.krakow.pl
}

Genet. Mol. Res. 13 (4): 10779-10786 (2014)

Received November 26, 2013

Accepted June 6, 2014

Published December 18, 2014

DOI http://dx.doi.org/10.4238/2014.December.18.19

\begin{abstract}
DNA isolation is a crucial step of conducting genetic studies in any organism. However, this process is quite difficult when studying fungi because of the need to damage the fungal cell walls of specific structures. In this study, we developed a method for the rapid and efficient isolation of fungal DNA based on simultaneous mechanical and enzymatic cell wall degradation. There are several typical modifications of the standard phenol-chloroform DNA extraction method. This method can be modified to degrade the fungal cell wall. The first step of the presented DNA extraction included manual homogenization in modified lysis buffer. Next, enzymatic digestion using 2 enzymes was conducted, including lyticase and proteinase $\mathrm{K}$. To carefully select the most favorable conditions, we developed an economical, rapid, and reliable method for fungal DNA extraction that ensures both high efficiency and proper purity, which are essential for further analyses.
\end{abstract}

Key words: DNA isolation; Fungi; Proteinase K; Lyticase 


\section{INTRODUCTION}

Fungi, like animals and plants, belong to the Eukaryota. There are an estimated 1.5 million fungal species on Earth, but few have been examined in detail (Hawksworth and Rossman 1997; Blackwell, 2011). Understanding and describing the remaining species are important for human health, environmental protection, and industrial development. Fungi participate in the biodeterioration of a wide variety of animal and plant products (Michaelsen et al., 2006). To protect all these products from the negative effects of fungi, a large number of species must be properly identified. The main limitation in identifying microorganisms is that only a low percentage of fungal species can be studied using classical culture methods. Identification methods for cultured fungi are based mainly on the morphological assessment of fungal colonies and structures with reference to fungal systematic keys. These methods are valuable and are used in many cases, but frequently identifying a strain or species requires a great deal of experience in the field, which can be problematic. In such cases, molecular biology techniques can be used (Balajee et al., 2007).

Molecular methods for fungi detection and identification are primarily based on the analyses of genetic material, particularly through the use of polymerase chain reaction (PCR) (Hue et al., 1999). DNA isolation is an initial and critical stage of genetic identification (Karakousis et al., 2006; Vazques-Angulo et al., 2012). Various studies have been conducted to determine effective DNA extraction methods (Griffin et al., 2002). Various methods have been developed to isolate DNA from fungal cells. However, because of the need to disrupt the fungal cell wall, specialized techniques are required (Al-Samarrai and Schmid, 2000). Methods of cell wall degradation include mechanical, physical, or enzymatic disruption. For example, homogenization in liquid nitrogen or grinding with glass beads can be applied (Manian et al., 2001; Karakousis et al., 2006; Sasidharan et al., 2012). Physical methods of cell wall disruption include disintegration by microwaves (Kulik et al., 2005) and sonification (van Burik et al., 1998). Methods based on the use of enzymes, such as proteinase K, lysozyme (Murray et al., 1998), zymolyase (Fujita et al., 1995; Ling et al., 1995), and lyticase (van Deventer et. al., 1995; Williamson et al., 2000), can also be used for cell wall destruction.

DNA extraction protocols should be highly efficient and result in sufficient purity of the nucleic acid for subsequent analyses (Karakousis et al., 2006). The aim of this study was to develop an economical, simple, and efficient method for isolating fungal DNA while ensuring the functionality of the derived genetic material. A protocol combining mechanical homogenization of the cell wall followed by enzymatic digestion is presented. The composition of lysis buffer proposed in this study was optimized to increase the efficiency and purity of DNA. In addition, application of 2 enzymes such as lyticase and proteinase $\mathrm{K}$ was compared to improve DNA isolation efficiency.

\section{MATERIAL AND METHODS}

The selected fungal strains included Alternaria alternata, Aspergillus versicolor, Penicillum brevicompactum, Chaetomium globosum, and Fusarium sp, which were inoculated on potato dextrose agar medium and incubated for 6 days at $30^{\circ} \mathrm{C}$. After incubation, $35 \mathrm{mg}$ of each fungal culture was collected using a sterile spatula and placed into sterile test tubes. 


\section{DNA extraction}

To isolate DNA, a modified protocol of the standard phenol-chloroform DNA extraction method was used (Byrd et al., 1990). Prepared samples from the fungal growth step were added to $500 \mu \mathrm{L}$ optimized lysis buffer $(100 \mathrm{mM}$ ethylenediaminetetraacetic acid, $100 \mathrm{mM}$ Tris- $\mathrm{HCl}, \mathrm{pH} 8,0.5 \mathrm{M} \mathrm{NaCl}, 3 \%$ sodium dodecyl sulfate) and homogenized using a manual homogenizer for 1-2 min. To compare the activity of enzymes in cell wall digestion, $400 \mathrm{U}$ lyticase or $1 \mathrm{mg} / \mathrm{mL}$ proteinase $\mathrm{K}$ was added. After mixing, the samples were incubated in a thermoblock for $18 \mathrm{~h}$ at $55^{\circ} \mathrm{C}$ while shaking at $550 \mathrm{rpm}$ (Biometra, Göttingen, Germany). To optimize enzyme activity, the lyticase treatment was carried out under 2 conditions. First, digestion by lyticase was carried out for $18 \mathrm{~h}$ followed by an additional digestion with proteinase $\mathrm{K}$ for $1 \mathrm{~h}$. Under the second condition, lyticase digestion was reduced to only $3 \mathrm{~h}$. After enzymatic digestion, $500 \mu \mathrm{L}$ phenol was added to each sample, and the samples were then mixed gently by inversion $(25 \mathrm{X})$ and centrifuged at $9500 \mathrm{~g}$ for $10 \mathrm{~min}$ at room temperature. Two phases were observed after centrifugation. The lower phase was discarded. The upper, aqueous phase was transferred to new $1.5-\mathrm{mL}$ tubes and after adding $250 \mu \mathrm{L}$ phenol and 250 $\mu \mathrm{L}$ chloroform and the samples were mixed as described above (20X). In the next stage, the samples were centrifuged at $9500 \mathrm{~g}$ for $10 \mathrm{~min}$ at room temperature. For DNA precipitation, the upper phase was transferred again to new sterile tubes, leaving the phase boundary undisturbed. Next, $500 \mu \mathrm{L}$ isopropanol was added to each sample and the tubes were mixed by inversion until white filaments had precipitated. The samples were centrifuged at 13,000 $g$ for $1 \mathrm{~min}$ at room temperature. The isopropanol was discarded, while the centrifugal pellet (precipitated DNA) was gently washed with $200 \mu \mathrm{L} \mathrm{70 \%} \mathrm{ethanol} \mathrm{(EtOH)} \mathrm{for} 10$ min. After centrifugation at $13,000 \mathrm{~g}$ for $1 \mathrm{~min}$ at room temperature, EtOH was extracted as fully as possible and the pellet was suspended in $100 \mu \mathrm{L}$ TE buffer. To vaporize residual $\mathrm{EtOH}$, the samples were placed in a heating block and incubated at $65^{\circ} \mathrm{C}$ for $20 \mathrm{~min}$.

\section{Gel analysis}

To each $10 \mu \mathrm{L}$ extracted DNA sample, $1 \mu \mathrm{L} 10 \mathrm{X}$ concentrated loading buffer (BlueJuice; Invitrogen, Carlsbad, CA, USA) was added and the sample was applied on a $1.3 \%$ agarose gel containing $0.1 \mu \mathrm{g} / \mathrm{mL}$ ethidium bromide. The results were visualized using an electrophoresis gel system (Biometra). The resulting PCR products (see next paragraph) were imaged similarly to the DNA samples on a $1.8 \%$ agarose gel.

\section{PCR amplification}

PCR amplification was carried out using standard fungal primers for the following internal transcribed spacer (ITS) regions: ITS1 [5'-tccgtaggtgaacctgcgg-3'], ITS2 [5'-gctgcgttctt catcgatgc-3'], and ITS4 [tcctcegcttattgatatgc] in appropriate configurations of ITS1 and ITS2 as well as ITS1 and ITS4 (White et al., 1990). The $25-\mu \mathrm{L}$ reaction mixture was composed of 18.2 $\mu \mathrm{L}$ water (double-processed tissue culture water; Sigma-Aldrich, St. Louis, MO, USA), $2.5 \mu \mathrm{L}$ $10 \mathrm{X}$ concentrated buffer (Invitrogen), $1.5 \mu \mathrm{L} 50 \mathrm{mM} \mathrm{MgCl}_{2}$ (Invitrogen), $0.5 \mu \mathrm{L}$ of each $10 \mathrm{pM} /$ $\mu \mathrm{L}$ forward and reverse primer (Genomed, Warsaw, Poland), $0.6 \mu \mathrm{L} 10 \mathrm{mM}$ dNTPs (SigmaAldrich), $0.25 \mu \mathrm{L} 5 \mathrm{U} / \mu \mathrm{L}$ Taq polymerase (Sigma-Aldrich), and $0.5 \mu \mathrm{L}$ DNA genomic solution. 
For ITS1 and ITS2 primers, PCR was carried out in a thermocycler (Biometra; T-gradient) under the following conditions: DNA predenaturation at $94^{\circ} \mathrm{C}$ for $5 \mathrm{~min}$ and 35 consecutive cycles consisting of DNA denaturation at $94^{\circ} \mathrm{C}$ for $30 \mathrm{~s}$, binding primers to the matrix at $54^{\circ} \mathrm{C}$ for $30 \mathrm{~s}$, and synthesis of the new complementary strand for $30 \mathrm{~s}$ at $72^{\circ} \mathrm{C}$. For the ITS 1 and ITS4 primers, the following protocol was used: DNA predenaturation at $94^{\circ} \mathrm{C}$ for $5 \mathrm{~min}$ and 35 consecutive cycles consisting of DNA denaturation at $94^{\circ} \mathrm{C}$ for $50 \mathrm{~s}$, binding primers to the matrix at $54^{\circ} \mathrm{C}$ for $50 \mathrm{~s}$, and synthesis of the new complementary strand for $50 \mathrm{~s}$ at $72^{\circ} \mathrm{C}$. After completing the last cycle for both primer pairs, final elongation was carried out for $10 \mathrm{~min}$ at $72^{\circ} \mathrm{C}$ and the samples were cooled to $4^{\circ} \mathrm{C}$. The primers ITS1 and ITS2 replicate the noncoding fragment of DNA (ITS1) between the coding DNA sequence for the $18 S \mathrm{r} R N A$ gene and the sequence of the 5.8S rRNA gene, resulting in a product of 132-290 bp (Schwarz et al., 2006; Vancov and Keen, 2009), while the primers ITS1 and ITS4 replicate the sequence of the entire region ITS1-5.8SITS2 to result in a product of 600-800 bp (Gardes and Bruns, 1993).

\section{Spectrophotometric analysis}

Quantitative and qualitative analysis of isolated DNA was carried out using a nanospectrophotometer (Pearl; IMPLEN, Munich, Germany) by applying $1.5 \mu$ L DNA suspension. The DNA concentrations in successive samples are shown in Table 1. DNA purity was also analyzed by analyzing $\mathrm{A}_{260} / \mathrm{A}_{280}$ ratios.

\section{Statistical analysis}

The DNA concentrations of all fungal strains tested are shown in Table 1 and reported as means of all experiments and the standard deviation. To compare DNA concentrations for 2 different test groups ( 2 incubation times with lysis buffer and digestive enzymes), the Student $t$-test was used; statistically significant differences were accepted at $\mathrm{P}<0.05$. Between 4 and 5 DNA extractions were performed for each fungus.

\section{RESULTS}

The derived fungal growth for the 5 different species after manual homogenization was digested in new lysis buffer with 2 different enzymes, proteinase $\mathrm{K}$ or lyticase, for approximately $18 \mathrm{~h}$ under appropriate conditions. Agarose gel electrophoretic analysis showed that better DNA recovery was achieved for digestion with lyticase than with proteinase $\mathrm{K}$ (Figures 1 and 2).

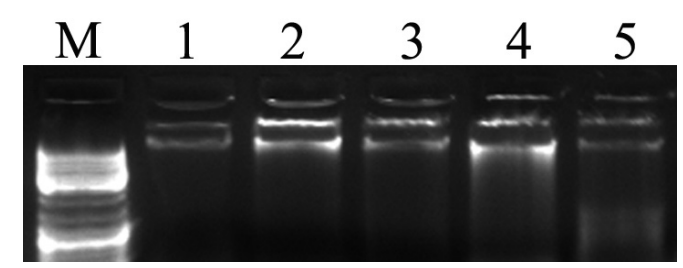

Figure 1. Agarose gel electrophoresis of DNA after isolation with digestion using only proteinase K. Lane $M=$ DNA marker (O'GeneRuler DNALadder Mix). Lanes 1-5 = the 5 different fungal isolates (A. alternata, A. versicolor, P. brevicompactum, C. globosum, Fusarium sp). 


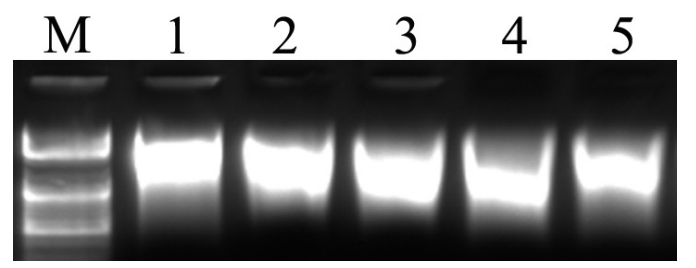

Figure 2. Agarose gel electrophoresis of DNA after isolation with only lyticase. Lane $M=$ DNA marker (O'GeneRuler DNALadder Mix), Lanes 1-5 = the 5 different fungal isolates (A. alternata, A. versicolor, $P$. brevicompactum, $C$. globosum, Fusarium sp).

However, the use of DNA for PCR was not always successful and unexpected products were sometimes obtained (data not shown). This may have resulted from high protein levels in the derived samples; to eliminate this problem, an additional digestion with proteinase $\mathrm{K}$ (for $1 \mathrm{~h}$ ) was conducted. This method provides satisfactory amounts of DNA of appropriate purity, and $\mathrm{A}_{260} / \mathrm{A}_{280}$ ratios for all samples were 1.79-2.00, enabling further genetic analyses. To accelerate the DNA isolation procedure, we attempted to shorten the incubation time of the fungal material with lysis buffer and individual enzymes. Activity times for which satisfactory results were obtained for particular enzymes were determined experimentally. Equally high efficiency and proper purity of derived DNA were achieved after incubation of fungal material in lysis buffer with lyticase for $3 \mathrm{~h}$ followed by 1 -h digestion with proteinase K. Nanospectrophotometric analysis revealed no statistically significant differences in the amount of obtained genetic material between DNA samples subjected to 18-h or 3-h digestion (Table 1). The amount of genetic material was considerably larger after 18-h digestion than after $3 \mathrm{~h}$ only for C. globosum and Fusarium sp.

Table 1. Comparison of DNA concentrations obtained during isolation at digestion times.

\begin{tabular}{llc}
\hline Strain & \multicolumn{2}{c}{ DNA concentration $(\mathrm{mg} / \mathrm{mL})$} \\
\cline { 2 - 3 } & \multicolumn{1}{c}{$\mathrm{A}$} & $\mathrm{B}$ \\
\hline Alternaria alternata & $177.2 \pm 28.5$ & $171.4 \pm 27.5$ \\
Aspergillus versicolor & $245.8 \pm 39.9$ & $260.9 \pm 49.4$ \\
Penicillum brevicompactum & $295.6 \pm 19.5$ & $301.3 \pm 58.7$ \\
Chaetomium globosum & $631.1 \pm 46.1^{*}$ & $463.7 \pm 126.5^{*}$ \\
Fusarium sp & $402.0 \pm 75.6$ & $332.1 \pm 48.3$ \\
\hline
\end{tabular}

$\mathrm{A}=$ incubation with lyticase for $18 \mathrm{~h}$ and then with proteinase $\mathrm{K}$ for $1 \mathrm{~h} . \mathrm{B}=$ incubation with lyticase for $3 \mathrm{~h}$ and then with proteinase $\mathrm{K}$ for $1 \mathrm{~h}$. The mean values with standard deviation $( \pm \mathrm{SD})$ and statistically significant differences $(* \mathrm{P}<0.05)$ are shown.

We obtained genetic material of sufficient amounts for further analyses. The functionality of the derived genetic material was verified through PCR by using standard primers for the ITS region. The primers ITS1 and ITS2 for the region ITS1 (White et al., 1990; Schwarz et al., 2006) and the primers ITS1 and ITS4 for the region ITS1-5.8S-ITS2 (Gardes and Bruns, 1993; Martin and Rygiewicz, 2005) were used with a modified reaction protocol (Zhang et al., 2010). Expected reaction products were obtained for both primer pairs in all samples both for the whole and shortened DNA isolation procedure (Figures 3 and 4). 


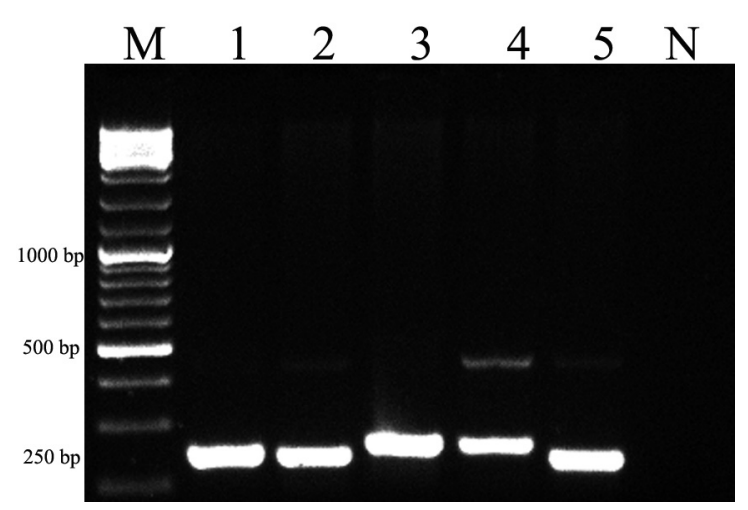

Figure 3. Electrophoresis of PCR products, using primers ITS1 and ITS2. Lane $M=$ DNA marker (O'GeneRuler DNALadder Mix). Lanes 1-5 = PCR products for A. alternata, A. versicolor, P. brevicompactum, C. globosum, Fusarium sp; lane $N=$ negative control.

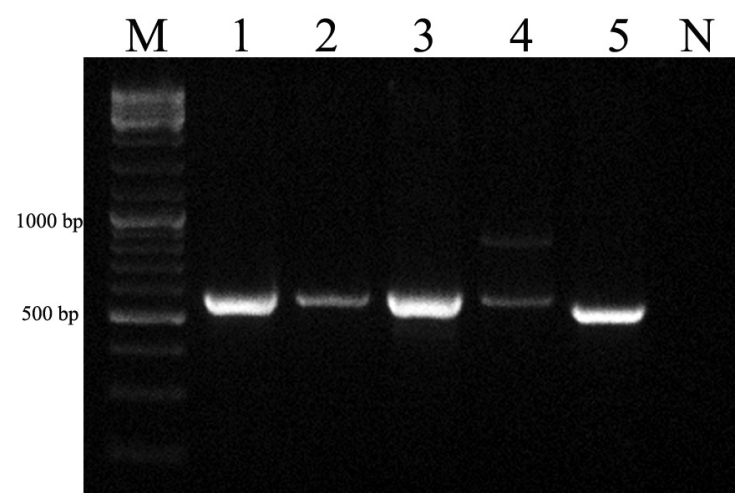

Figure 4. Electrophoresis of PCR products, using primers ITS1 and ITS4. Lane $M=$ DNA marker (O'GeneRuler DNALadder Mix). Lanes 1-5 = PCR products for A. alternata, A. versicolor, P. brevicompactum, C. globosum, Fusarium sp; lane $N=$ negative control.

\section{DISCUSSION}

The development of accurate and reliable methods for fungus identification has increased; most of these methods are based on sensitive PCR to enable the use of specific genetic markers (Hou et al., 2013). DNA extraction is an important initial step of genetic identification of fungi. Thus, we optimized different steps of the fungal DNA isolation procedure to obtain pure and functional genetic material in satisfactory amounts without the need for expensive kits. Lysis buffer was prepared based on published methods and our observations (Byrd et al., 1990; Manian et al., 2001; Harju et al., 2004; Gonzalez Mendoza et al., 2010; Zhang et al., 2010; Vazquez-Angulo et al., 2012). We then compared the effectiveness of the enzymes proteinase $\mathrm{K}$ and lyticase to digest fungal cell walls. Better DNA recovery was observed after lyticase treatment, which is consistent with results of Karakousis et al. (2006). To improve the DNA isolation procedure, we conducted double-digestion with the 2 enzymes and shortened the time of incubation with various enzymes. 
The combination of our optimized lysis buffer and selection of activity time for successive enzymes, lyticase and proteinase $\mathrm{K}$, provides an economical, rapid, and simple procedure for DNA extraction from fungal cells, resulting in the isolation of genetic material that can be used for further analyses.

\section{REFERENCES}

Al-Samarrai TH and Schmid J (2000). A simple method for extraction of fungal genomic DNA. Lett. Appl. Microbiol. 30: 53-56.

Balajee SA, Sigler L and Brandt ME (2007). DNA and the classical way: identification of medically important molds in the 21st century. Med. Mycol. 45: 475-490.

Blackwell M (2011). The fungi: 1, 2, 3 ... 5.1 million species? Am. J. Bot. 98: 426-438.

Byrd AD, Schardl CL, Songlin PJ, Mogen KL, et al. (1990). The beta-tubulin gene of Epichloë typhina from perennial ryegrass (Lolium perenne). Curr. Genet. 18: 347-354.

Fujita S, Lasker BA, Lott TJ, Reiss E, et al. (1995). Microtitration plate enzyme immunoassay to detect PCR-amplified DNA from Candida species in blood. J. Clin. Microbiol. 33: 962-967.

Gardes M and Bruns TD (1993). ITS primers with enhanced specificity for basidiomycetes - application to the identification of mycorrhizae and rusts. Mol. Ecol. 2: 113-118.

González Mendoza D, Argumedo Delira R, Morales Trejo A, Pulido Herrera A, et al. (2010). A rapid method for isolation of total DNA from pathogenic filamentous plant fungi. Genet. Mol. Res. 9: 162-166.

Griffin DW, Kellogg CA, Peak KK, Shinn EA (2002). A rapid and efficient assay for extracting from fungi. Lett. Appl. Microbiol. 34: 210-214.

Harju S, Fedosyuk H and Peterson KR (2004). Rapid isolation of yeast genomic DNA: Bust n' Grab. BMC Biotechnol. 4: $1-4$.

Hawksworth DL and Rossman AY (1997). Where are all the undescribed fungi? Phytopathology 87: 888-891.

Hou JM, Ma BC, Zuo YH, Guo LL, et al. (2013). Rapid and sensitive detection of Curvularia lunata associated with maize leaf spot based on its Clg2p gene using semi-nested PCR. Lett. Appl. Microbiol. 56: 245-250.

Hue FX, Huerre M, Rouffault MA and de Bievre C (1999). Specific detection of Fusarium species in blood and tissues by a PCR technique. J. Clin. Microbiol. 37: 2434-2438.

Karakousis A, Tan L, Ellis D, Alexiou H, et al. (2006). An assessment of the efficiency of fungal DNA extraction methods for maximizing the detection of medically important fungi using PCR. J. Microbiol. Methods 65: 38-48.

Kulik T, Fordoński G, Pszczółkowska A, Płodzień K, et al. (2005). Identyfikacja wybranych gatunków grzybów z rodzaju Fusarium z nasion niektórych gatunków roślin uprawnych metodą tradycyjną i BIO-PCR. Acta Agrobot. 58: 33-54.

Ling M, Merante F and Robinson BH (1995). A rapid and reliable DNA preparation method for screening a large number of yeast clones by polymerase chain reaction. Nucleic Acids Res. 3: 4924-4925.

Manian S, Sreenivasaprasad S and Mills PR (2001). DNA extraction method for PCR in mycorrhizal fungi. Lett. Appl. Microbiol. 3: 307-310.

Martin KJ and Rygiewicz PT (2005). Fungal-specific PCR primers developed for analysis of the ITS region of environmental DNA extracts. BMC Microbiol. 5: 1-11.

Michaelsen A, Pinzari F, Ripka K, Lubitz W, et al. (2006). Application of molecular techniques for identification of fungal communities colonising paper material. Int. Biodeterior. Biodegradation 58: 133-141.

Murray AE, Preston CM, Massana R, Taylor LT, et al. (1998). Seasonal and spatial variability of bacterial and archaeal assemblages in the coastal waters near Anvers Island, Antarctica. Appl. Environ. Microbiol. 64: 2585-2595.

Sasidharan K, Amariei C, Tomita M and Murray DB (2012). Rapid DNA, RNA and protein extraction protocols optimized for slow continuously growing yeast cultures. Yeast 29: 311-322.

Schwarz P, Bretagne S, Gantier JC, Garcia Hermoso D, et al. (2006). Molecular identification of zygomycetes from culture and experimentally infected tissues. J. Clin. Microbiol. 44: 340-349.

van Burik JA, Schreckhise RW, White TC, Bowden RA, et al. (1998). Comparison of six extraction techniques for isolation of DNA from filamentous fungi. Med. Mycol. 36: 299-303.

van Deventer AJ, Goessens WH, van Belkum A, van Vliet HJ, et al. (1995). Improved detection of Candida albicans by PCR in blood of neutropenic mice with systemic candidiasis. J. Clin. Microbiol. 33: 625-628.

Vancov T and Keen B (2009). Amplification of soil fungal community DNA using the ITS86F and ITS4 primers. FEMS Microbiol. Lett. 296: 91-6.

Vazquez Angulo JC, Mendez Trujillo V, González Mendoza D, Morales Trejo A, et al. (2012). A rapid and inexpensive

Genetics and Molecular Research 13 (4): 10779-10786 (2014)

CFUNPEC-RP www.funpecrp.com.br 
method for isolation of total DNA from Trichoderma spp (Hypocreaceae). Genet. Mol Res. 11: 1379-1384.

White TJ, Bruns TD, Lee S and Taylor J (1990). Analysis of phylogenetic relationships by amplification and direct sequencing of ribosomal RNA genes. In: PCR Protocols: a Guide to Methods and Applications (Innis MA, Gelfand DH, Sninsky JJ and White TJ, eds). Academic Press, New York, 315-322.

Williamson EC, Leeming JP, Palmer HM, Steward CG, et al. (2000). Diagnosis of invasive aspergillosis in bone marrow transplant recipients by polymerase chain reaction. Br. J. Haematol. 108: 132-139.

Zhang YJ, Zhang S, Liu XZ, Wen HA, et al. (2010). A simple method of genomic DNA extraction suitable for analysis of bulk fungal strains. Lett. Appl. Microbiol. 51: 114-118. 